\title{
Cell cycle length and long-time behaviour of an age-size model
}

\author{
Ryszard Rudnicki ${ }^{1}$ and Katarzyna Pichór ${ }^{2}$ \\ ${ }^{1}$ Institute of Mathematics Polish Academy of Sciences \\ ${ }^{2}$ University of Silesia
}

April 28, 2021

\begin{abstract}
We consider an age-size structured cell population model based on the cell cycle length. The model is described by a first order partial differential equation with initial-boundary conditions. Using the theory of semigroups of positive operators we establish new criteria for an asynchronous exponential growth of solutions to such equations. We discuss the question of exponential size growth of cells. We show how to incorporate into our description models with constant increase of size and with target size division. We also present versions of the model when the population is heterogeneous.
\end{abstract}

\section{Hosted file}

KP-RR-cell-cycle-struct-population_MMAS.pdf available at https://authorea.com/users/294120/ articles/519999-cell-cycle-length-and-long-time-behaviour-of-an-age-size-model 